\title{
B9D2 wt Allele
}

National Cancer Institute

\section{Source}

National Cancer Institute. B9D2 wt Allele. NCI Thesaurus. Code C113280.

Human B9D2 wild-type allele is located in the vicinity of $19 q 13.2$ and is approximately 10

$\mathrm{kb}$ in length. This allele, which encodes B9 domain-containing protein 2, is involved in

ciliogenesis. Mutation of the gene is associated with Meckel syndrome 10. 